\title{
PANCASILA AND RADICALISM: PANCASILA ENCULTURATION STRATEGIES AS RADICAL MOVEMENT PREVENTIONS
}

\author{
Sudjito, Hendro Muhaimin, and Agung Saras Sri Widodo \\ Pusat Studi Pancasila, Universitas Gadjah Mada, Yogyakarta - Indonesia \\ Email: sudjito_fh_ugm@yahoo.com
}

\begin{abstract}
Indonesia has defined Pancasila as nation's ideology which taught people to live with tolerance. Most Indonesian people embraced Islam and some sects such as salafi, wahabi, jama'ah tabligh, ikhwanul muslimin, and hizbut tahrir which offer alternative for Muslim to know and understand in practising Islamic values individually, group or country (Daulah Isamiyah). The emergence of those various teachings organizations become Islam dynamic. Religion (Islam)-based Radicalism movement is deemed to contradict the state ideology, Pancasila. This article tries to examine organizations or Islamic movement which should be tolerable, respect (lakum dinukum waliyadin), and keep the sovereignty of state. Thus, any Islamic movements that are not based on those principles are convinced that they do not come from Indonesian which is identical with local wisdom and plurality.
\end{abstract}

Keywords: ideology, Pancasila, radicalism, Islam, terrorism

\begin{abstract}
Abstrak
Indonesia sudah menetapkan Pancasila sebagai ideologi bangsa mengajarkan warganya untuk senantiasa hidup dengan penuh rasa toleran. Sebagian besar warganegara Indonesia menganut agama Islam, dan masuknya berbagai paham aliran seperti; salafi, wahabi, jama'ah tabligh, ikhwanul muslimin, dan hizbut tahrir menjadi alternatif pilihan bagi umat Islam untuk mengenal dan memahami konteks pengamalan nilai-nilai Islam baik dalam ranah individu, komunitas, bahkan negara (Daulah Islamiyah). Kemunculan berbagai aliran dan organisasi tersebut menjadi sebuah dinamika ke-Islam-an. Gerakan radikalisme yang berlatar belakang agama (Islam) diindikasikan tidak sesuai dengan ideologi negara yakni Pancasila. Artikel ini mencoba menempatkan keorganisasian maupun gerakan ke-Islam-an yang seharusnya hidup dan berkembang di masyarakat ialah gerakan yang dijiwai oleh semangat toleransi, saling menghormati (lakum dinukum waliyadin), dan menjaga kedaulatan negara. Jika kemudian ada gerakan Islam yang justru mengindahkan prinsip-prinsip tersebut bisa dipastikan gerakan tersebut bukan berasal dari Indonesia, dalam pengertian menjadikan kearifan lokal dan pluralisme sebagai dasar pijakan.
\end{abstract}

Kata kunci: ideology, Pancasila, radikalisme, culture, Islam, terorisme

\section{Introduction}

Radicalism as a view is not always materialized through violence but also non violent thought and ideology. The potential radicalism

See and read how ideologies have an effect on radical movements on: Masdar Hilmy, "Genealogi dan Pengaruh Ideologi Jihadisme Negara Islam Iraq dan Suriah (NIIS) d Indonesia", Teosofi: Jurnal Tasawuf dan Pemikiran Islam, Vol. 4 No. 2, Desember 2014, pp. 404-428; Moh. Sholehuddin, "Ideologi Religio-Politik Gerakan Salafi Laskar Jihad Indonesia", Jurnal Review Politik, Vol. 03, No. 1, Juni 2013, pp. 47-68; and M. Zaki Mubarak, "Dari NII ke ISIS: Transformasi Ideologi dan Gerakan dalam Islam Radikal di Indonesia Kontemporer", Episteme, Vol. 10 No. 1, Juni 2015, pp. 77-98

2 Along with technological advances, the global movement has easily entered Indonesia and has a marked influence determined by individual perception is not merely influenced by a certain ideology ${ }^{1}$ but also caused by a variety of factors in a global, ${ }^{2}$ regional, or local issues. ${ }^{3}$ For example, terrorism in

on radical movements. Read the explanation on: Hani Nesira, "Who Leads Global Jihad, al-Qaeda or ISIS?", alArabiya Institute for Studies, 19 Juni 2014, www.alarabiya.net, akses 5 Desember 2017; Thomas Hegghammer, "Global Jihadism after the Iraq War", Middle East Journal, Vol. 60, No. 1, 2006; pp. 11-32; Farid Esak, "Global Insecurities vs Perlawanan Global", Tradem, Fourth Edition, Januay 2003-March 2003, pp 42-43; and Sokhi Huda, "Terorisme Kontemporer Dunia Islam", Teosofi: Jurnal Tasawuf dan Pemikiran Islam, Vol. 4 No. 2, Desember 2014, pp. 429-450;

3 The dynamics of radical movements at the local and national levels, visible from the various actions taken by 
Indonesia, it emerged from a fanaticism by selftruth claiming which results in weapons use and bombings.

Religious ideology tends to be a motivation to justify violence. Violence enforcement in the name of religion is deemed to be a basic struggle of belief and as a form of kaffah religion. It makes some religious groups prioritize more on religious doctrine rather than tolerance with love and respect in accordance with human rights. ${ }^{4} \mathrm{~A}$ huge range of diverse expressions develop along with particular political tendencies in form of establishment of Islamic state as the influence of transnational movement regardless local wisdom. ${ }^{5}$

Religion tends to be legitimized to hide the actual conflict. ${ }^{6}$ Theological aspect or religion influences somehow stimulate the emerge of radicalism by its bipolar concept: self truth claiming while others are wrong or deserve heaven more than others and there is a history resentment in every religion development. ${ }^{7}$ Al-Jabiri said that radicalism is not merely a social political phenomenon covered by religious issues.

\section{Radicalism: Meaning and Background}

Etymologically, radicalism derives from radix that means to act radically or get to the roots. ${ }^{8}$ Thinking radically also means thinking deeply to reach the roots which most likely to trigger anti-establishment attitudes. Therefore, radicalism can be understood as an attitude

them. Read the explanations of local and national movements on: Erich Kolig, "Radical Islam, Islamic Fervor and Political Sentiments in Central Java, Indonesia", European Journal of East Asian Studies, No. 4 Vol. 1, 2005; pp. 55-86; Khoirul Faizin, "Fundamentalisme dan Gerakan Radikal Islam Kontemporer di Indonesia", Edu-Islamica, Vol. 5 No. 2, September 2013, pp. 344-367; Mohammad Kosim, "Pesantren dan Wacana Radikalisme", Jurnal Karsa, Vol. IX, No. 1, April 2006, p. 843; and Syamsul Arifin, "Membendung Arus Radikalisasi di Indonesia", ISLAMICA: Jurnal Studi Keislaman, Vol. 8, No. 2, Maret 2014, p. 392-420;

4 Machasin, "Fundamentalisme dan Terorisme", in A. Maftuh Abegebriel, et.al (eds)., 2003, Negara Tuhan: The Thematic Encyclopedia, Yogyakarta: Pustaka Pelajar, p. 121-127. Not all doctrines have negative connotations, some are positive. Read about it at: Abdul Munir Mulkhan, "Transformasi Doktrin untuk Keunggulan Hidup", Jawa Pos, 1 Oktober 2009;

5 See also on: Imam Mustofa, "Terorisme: Antara Aksi dan Reaksi (Gerakan Islam Radikal sebagai Respon terhadap which crave for a change by resenting the status quo for something totally different. Commonly, it uses revolutionary method by drastically overturning the existing values through violence and extreme actions. ${ }^{9}$

In Arab language, radicalism is known as several terms such as al-unf, al-tatarruf, al-guluww. Al-unf is violence act by illegal force (vigilante) to enforce their will. ${ }^{10} \mathrm{Al}$-tatarruf is derived from the word al-tarf which means tip or edge. It means being on the tip or edge both on the left or right edge. Hence, the word means radical, extreme, and excessive. So, al-tatarruf al-dini is all immoderate things in religion, that is opposite from word al-wasath (centre/moderate) that means good and admirable.

Based on the meaning, it can be concluded that radicalism is a view (ism), the action attached to someone or group who yearn for social or political change by violence, fundamental thinking, and extreme acts. Moreover, radicalism based on the exclusive paradigm, negating others, rigid, closed, extremism and sometimes military.

Radicalism has various terms, some called radicalism as fundamentalism, some also call it as extremism even some people tied it up with terrorism. Those terms constitutes similar meaning to some extent. If radicalism considers as notion referring to violence, fundamentalism is interpreted as notion that fights for something radically. Meanwhile extremism is understood as

Imperialisme Modern)", RELIGIA: Jurnal Studi Agamaagama, Vol. 15 No. 1, April 2012, pp. 65-87;

6 Muh. Khamdan, 2015, Bina Damai Terorisme, Kudus: Parist, p. 40; The way to cover it is to say that it is only a social conflict, not an interfaith conflict. See on: St. Aisyah BM, "Konflik Sosial dalam Hubungan Antar Umat Beragama", Jurnal Dakwah Tabligh, Vol. 15, No. 2, Desember 2014, pp. 189-208;

7 Mark Jurgensmayer, 2001, Terror in the Mind of God: The Global Rise of Religious Violence, California: University of California Press, p. 14-15; James M. Lutz dan Brenda J. Luts, 2004, Global Terrorism, London: Routledge, p. 74-78. Compare this issue to the article: Masdar Hilmy, "The Politics of Retaliation: The Backlish of Radical Islamist against Deradicalization Project in Indonesia", Al-Jami'ah, Vol. 51, No. 1, 2013/2014, pp 129-158;

8 John M. Echols dan Hassan Shadily, 1995, Kamus Inggris Indonesia, Jakarta: Gramedia.

9 Marx Juergensmeyer, op.cit

10 Lajnah Pentashihan Mushaf al-Qur'an Kementerian Agama, 2014, Tafsir al-Qur"an Tematik Jilid I, Jakarta: Kamil Pustaka, p. 97. 
a notion that tends to be extreme (strong). ${ }^{11}$ Furthermore, terrorism frequently tied to radicalism since terrorism means using violence to cause fear in order to reach particular group goals. ${ }^{12}$

In regards to this, radically thinking, behavior and act potentials correlate. Radical ideology (radicalism) which highly grows to be radicalization is one's initial motivation to be a terrorist. There is no terror without radicalism. In contrast, radicalism followers do not necessarily like violence (terror). However, there is language similarity used by radicalism or terrorism, militant language.

Philosophically, the religious radicalism is an issue related to core experience, collective memory and religious interpretation. ${ }^{13}$ In religious context, there is no shared agreement to describe the radical movement itself. To clarify religious radicalism phenomenon, what proposed by a religious sociologist, Martin E. Marty, with some modifications is quite relevant to be applied to observe the violence indications in the name of religion. According to him, the main indication is oppositionalism. It is a belief of threats resistance that may threaten the existence of the religion, such as modernity, secula-

11 Bahtiar Effendi dan Hendro Prasetyo, (eds), 1998, Radikalisme Agama, Jakarta: PPIM-IAIN, p. xvi. The explanation of the meaning of fundamentalism can be read in the following passage: Dwi Ratnasari, "Fundamentalisme Islam", Komunika: Jurnal Dakwah dan Komunikasi, Vol. 4 No. 1, Januari-Juni 2010, pp. 40-57; Azyumardi Azra, "Fenomena Fundamentalisme dalam Islam", Ulumul Qur'an, Vol. IV nO. 3, 1993; Abdurrahman Kasdi, "Fundamentalisme Islam Tmur Tengah: Akar Teologi, Kritik Wacana dan Politisasi Agama", Tashwirul Afkar, $13^{\text {th }}$ Edition, 2002; p.20; Bassam Tibbi, "Kaum Fundamentalis Jadikan Islam sebagai Ideologi Politik", Tashwirul Afkar, $13^{\text {th }}$ Edition, 2002; p. 118; Biyanto, "Fundamentalisme dan Ideologi Islam Modern", PARAMEDIA, Vol. 7 No. 2, April 2006; p. 17; and Anwar-ul-Haq Ahady, "The Decline of Islamic Fundamentalism", Journal of Asia and African Studies XXVII, 3-4 (1992): 231.

12 Departemen Pendidikan dan Kebudayaan, 1995, Kamus Besar Bahasa Indonesia, Jakarta: Balai Pustaka, p. 281.

13 J.B. Banawiratma, 1993, Bersama Saudara-Saudari Beriman Lain: Perspektif Gereja Katolik, in Dialog: Kritik dan Identitas Agama, Yogyakarta: Dian Interfidei. Compare this notion to what some authors say in their respective works: Syamsul Bakri, "Islam dan Wacana Radikalisme Agama Kontemporer”, Jurnal DINIKA, Vol. 3 No. 1, Januari 2004; Mona Abaza, "The Discourse on Islamic Fundamentalism in the Middle East and Southeast Asia: A Critical Perspective", Sojourn, Vol. 6, 1991, pp. 203239; William E. Shepard, "Fundamentalism Christian and rism, and mainly Western values. This resistance is done such as fight back the group that threatens the existence or identity of life; fight for dreams which includes life problems in general, such as family and social institutions; fight with framework of value or certain identity that comes from the legacy or new construction; fight against certain enemies that come in form of community or deviating-perceived religious social system; they do it in framework of fight under the name of God.

The background of the radicalism which emerges sociological-empirically cannot be separated from internal dynamics of the society itself. This is based on some internal and external factors. Radicalism rise in Islam is not an abrupt phenomenon. It emerged in political, economic and social-cultural situation which Islam radicalism followers perceive it discrediting Islam. Muslims in politics is not only disadvantaged but also unfairly treated. They believe that their aspirations are not well accommodated since the current political system (they called it kafir system) tends to take secular-nationalist side rather than Muslim's. ${ }^{14}$

Furthermore, the effect of religious radicalism can emerge radicalization of religious

Islamic", Religion, Vol. 17, No. 1, 1987, pp. 355-378; William E. Shepard, "What is Islamic Fundamentalism?", Studies in Religion, Vol. 18, No. 1, 1988, pp. 5-25; Abdul Mukti Ro'uf, “Mengurai Radikalisme Agama di Indonesia Pasca Orde Baru”, Ulumuna: Jurnal Studi Keislaman, Vol. XI, No. 1, Juni 2007, pp. 157-176; and Ahmad Fuad Fanani, "Radikalisme dan Pembiaran", Kompas, 30 April 2011.

14 Indonesia is a fertile ground for the growth of radicalism. Read it at: Azumardi Azra, "Radikalisme Islam Indonesia”, Tempo, 15 Desember 2002; Ahmad Asrori, “Radikalisme di Indonesia: Antara Historisitas dan Antropisitas", Kalam: Jurnal Studi Agama dan Pemikiran Islam, Vol. 9 No. 2, Desember 2015, pp. 253-268; Khudzaifah Dimyati, Muhammad Busjro Mugoddas dan Kelik Wardiono, "Radikalisme dan Peradilan: Pola-pola Intervensi Kekuasaan dalam Kasus Komando Jihad di Indonesia", Jurnal Dinamika Hukum, Vol. 13 No. 3, September 2013, pp. 379 391; Michael Davis, "Laskar Jihak and the Political Position of Conservative Islam in Indonesia", Contemporary Southeast Asia, Vol. 24, 2002; Masdar Hilmy, "Radikalisme Agama dan Politik Demokrasi di Indonesia PascaOrde Baru", MIQOT, Vol. XXXIX, No. 2, Juli-Desember 2015, 407-425; Martin van Bruinessen, "Genealogies of Islamic Radicalism in post-Suharto Indonesia", South East Asia Research, Vol. 10 No. 2, 2002, pp. 131-134; and Saifuddin, "Radikalisme di Kalangan Mahasiswa, Sebuah Metamorfosa Baru", Islamic Study Journal Analysis, Vol. XI No. 1, June 2011, 28-29. 
movement. As Endang Turmudzi said it occurs as a result of the increased religious fundamentalism of its adherents caused by a strong desire to practice the doctrines of their religion in form of ideal society, challenge of domestic reality and international politic constellation which damages social-political life of Muslims. Meanwhile Dahrendorf stated three conditions that support the emerge of struggle group and also trigger conflicts including: first, constant communication among people on the same boat; second, there is a leader that helps articulate ideology, organizes the group and formulates the plan for group's action; and third, group's legitimacy in community's wider perspective-or at least there are no effective community's pressure towards the group. ${ }^{15}$

Therefore, the emergence of radicalism sporadically in the world does not come from an empty space. The fact that appears in society is a reckless attitude from people who judge Islam as the ringleader of radicalism and terrorism movement. Islam is stigmatized as a threat of peace in the world just due to some groups' action. Those who do not have the actual understanding of Islam will easily accept the negative perspective and stigma. Hence, it requires a real action such as socialization of peaceful and moderate Islamic teaching to be the spirit of peace.

It is not fair if the emerge of various chaos in this world is assumed as the effort of Islam fundamentalism to construct a new world order and replace the western. It is not fair either if Islam is positioned as the ringleader of the existing chaos, radicalism, or terrorism nowadays. Anyone who wants to identify and analyze indications of radicalism and terrorism must able to differentiate Islam as a religion from Islam as political ideology. Islam as religion and civilization is one thing while Islam as political ideology is another different thing. Treating both the sa-

15 Endang Turmudzi dan Riza Sihbudi (ed.), 2005, Islam dan Radikalisme di Indonesia, Jakarta: LIPI Press, p. 1-

16 Ali Shari‘ati, 1993, Ideologi Kaum Intelektual: Suatu Wawasan Islam, (edited by Syafiq Basri dan Haidar Bagir), Bandung: Mizan, p. 80. See also: William E. Sephard, "Islam and Ideology: Toward a Typhology", International Journal of Middle East Studies, Vol. 19, 1987, pp 305- me is frivolous and shows superficial understanding about Islam.

Ideology, in any forms, is a force that deconstructs every static life order and a liberator of any form of oppression that befall upon human. Ali Shari'ati neatly elaborated the relation between religion and ideology and the differentiating side of both. According to him, religion basically consists of two kinds: first, religion as ideology; and second, religion as collection of traditions, social conventions or collective spirit of a group. ${ }^{16}$

Radicalism and terrorism action done by radicals and terrorist always justify their action as jihad (holy war). This is fundamentally wrong. Since the concept of jihad itself is not holistically and comprehensively understood. The important question is whether their action is the suggested one in Islam? Perhaps the terrorist who confessed it as jihad does not understand the meaning jihad itself. They only know the surface not what the content beneath is. It will be more dangerous if what they called jihad is an effort to misappropriation of Holy Qur'an and Hadith.

In Al-Qur'an and Hadith, command to jihad has already been written in some verses and Hadith' contents. Unfortunately, the verses and hadith that mention about the concept of jihad have often been haphazardly interpreted. The subjective interpretation and far from scientific study have become the justification and stimuli for some Islamic movements then it stigmatizes to all Muslims.

This is where many movements appear by politicizing religion that essentially contradicts the substance of the religion itself. As a result, the phenomenon of radicalism in religion, once again, should not be understood that the religion value is the wrong one but actually it is caused by the mistaken understanding towards the religion teaching (read: jihad) and also caused by

307; Masdar Hilmy, "Radikalisme, Demokrasi dan Pancasila”, Kompas, 12 September 2014; p 7; Ahmad Nur Fuad, "Interrelasi Fundamentalisme dan Orientasi Ideologi Gerakan Islam Kontemporer”, ISLAMICA, Vol. 2 No. 1, September 2007, pp. 16-26; M. And Syafi'i Anwar, “Dekonstruksi Fatalisme Keagamaan”, Jawa Post, 26 September 2009; 
social, economic, and political factors. The religion comprehension cannot stand alone. Aspects of social, environment, education, and politics also take part in building up one's religion comprehension.

From this point, religion seems to have a manifest functions which is well understood by participants as objective manifestation from a social system. For instance,to improve people connectedness (ukhuwah islamiyah), or it has latent function which is not expected by the social system dealing with radicalism. According to Azyumardi Azra, religion is a sitting duck to be a crying banner in doing the anarchy action (radicalism), and also be based on the textual construction that existed in the religion itself.

In this context, religion has two contradictory sides. One side is about the great strength in uniting people from any different background, on the other side, the subjective comprehension can also be the potential cause of radicalism. Here we see how the comprehension of religion can create the radicalism and terrorism action that will destroy the social harmony.

\section{The Pancasila Reinforcement to Prevent Radi- cal Movements}

Basically, the existence of radicalism aims to change the order of Indonesia state by Islam which contradicts Pancasila. Nowadays, many provocations are thrown to spark Muslim anger. Whereas, people know that Muslims are easily provoked when their religion is teased. Nowadays, Islam has been divided into many ideologies that may bring a conflict among Muslims. Accordingly, we must concern this issue that is able to destroy the values of Pancasila by working together in strengthening Pancasila value considering the violence and radicalism have become the threat of the ideological resilience of Pancasila nowadays.

To tighten the unity of the nation there are several concerns like avoiding to distinguish people by seeing their societal group, nations, religions, races, and anything; uphold the human rights and respect for each other; then all problem that rises from the social interaction must be discussed in a good way and well accommodated to any perspectives; we must give the chance to others to do according to their beliefs peacefully.

Pancasila is a way of life, a view of life (weltanschauung), and a life guidance (Wereld en levens beschouwing). Pancasila must be carried out in the daily life, using it as guidance in all daily basis and used in all aspects in this life such as politics, education, religion, culture, social, and economy. It means that all Indonesian behaviour must reflect Pancasila values. For Indonesia, the ideology of Pancasila is very meaningful especially to the citizen. Moreover, Pancasila is also the guidance to do any activities in state living. Pancasila is a character of Indonesia. Then Pancasila has to be internalized in citizen's life, becomes the principle in social communication between the people, and becomes the guidance in harmonizing the life of the different believers in Indonesia.

The ideology of Pancasila owned by Indonesia is the very ideal and suitable ideology with Indonesian characteristics of different beliefs, societal group, customs, characters, and languages. In this regards, our founding fathers wished to unite all variety that existed in Indonesia and solve any differences by uniting Indonesia. Hence, the Ideology of Pancasila has the openness characteristics by always keeping and selectively selecting the other ideology to enter Indonesia.

All activities that may bring the radicalism and contradictory propaganda towards nation's ideology has become the responsibility for all Indonesia community to control and to oversee any movement that allegedly changes the form and foundation of state. Pancasila, as the view of life must be the foundation of all aspects. Pancasila has reflected how to behave, talk, and act. As the foundation, Pancasila has a noble value, character, ethics, and moral to be implemented by Indonesian people in order to build the sense of nationality and sense of unity, instead of spreading the seed of hatred to Pancasila. 
Pancasila is an ideology that is inseparable from religious and spiritual aspects. Pancasila first principle, the one and only God, is briefly explained that human has to believe in God of religious people. Hence, Pancasila gives freedom to Indonesian people to freely and consciously practice their religious activities. Pancasila as the national ideology functions as the goal which is in line with the ideology main function and as media to unite the people or conflict negotiator. Pancasila as the ideology was established with a purpose, as a means to unite the diverse Indonesian people such as Islam, Christianity, Catholic, Hinduism, and Buddhism.

Pancasila Ideology is values order which is derived from the basic value of Indonesian culture. Its principles are a unity so the understanding and the implication should include the whole values in those principles. The ideology endurance means the dynamic condition of Indonesian ideological life including the tenacity and strength which contain national power ability to solve any direct/indirect challenge, threat, obstacle and internal/external interference to preserve Indonesian people and nation ideology life. To realize this, the people must believe in Pancasila as the people and national ideology and consistently implement the principles.

Therefore, by consolidating Pancasila as state base, it is expected to repel the radical ideology and intolerance acts that aim to destroy our final ideology as the life guidance of Indonesian people. If there are some people or religious organization that do not agree with Pancasila as the state ideology, it means they violate the Social Organization Law and they need to be exterminated as well as their ideology. We must develop balance mind in binding harmonious relationship between religion and state because both are inseparable combination.

17 Efforts to deradicalisation is continuously done by involving various parties. Read the explanation of this on: Abu Rokhmad, "Pandangan Kiai tentang Deradikalisasi Paham Islam Radikal di Kota Semarang", Jurnal "Analisa", Vol. 21 No. 01 Juni 2014, pp. 27-37; Abu Rokhmad, "Radikalisme Islam dan Upaya Deradikalisasi Paham Radikal", Walisongo, Vol. 20 No 1, Mei 2012, pp. 79-114; Masnun Tahir, "Wacana Fikih Kebangsaan dalam Penanggulangan dan Pencegahan Radikalisme di Lingkungan Kampus di NTB", Asy'Syir'ah: Jurnal Ilmu Syari'ah dan Hukum, Vol.
Accordingly, it is necessary to respect Pancasila as our ideology, back to Pancasilaas ideology spirit, and to implement the values. Return to Pancasila is crucial to prevent radicalism. Pancasila has obvious role and functions to manage human behaviour in the society, state, and religion. Thus, the radicalism ideology brought by certain religious organization must be controlled and under the supervision of all parties. This organization absolutely will destroy Pancasila as the final state base, life vision and guidance.

Consequently, every activity of religious organization must represent Pancasila's values. Pancasila as Indonesian philosophical system which is full of good characters, wisdom, and morality has to be implemented by all Indonesian people and the undergraduate students. It should be the base principle in holding the organization as the fortress to prevent radicalism, intolerance, and terrorist acts. Therefore, Pancasila is definitely relevant to destroy radicalism mindset. We must return to Pancasila mindset. By doing so, we have to obey the Indonesian law and philosophical system.

\section{Deradicalization Policy}

Deradicalization etymologically comes from the word 'radical' added by prefix 'de' that means abolishing, removing, or eliminating something. It can be interpreted as an effort to abolish, remove or eliminate the radical acts. Based on the etymology, deradicalization of religious understanding means an effort to eliminate the radical understanding. It does not aim to deliver a new understanding but to emphasize the holistic and contextual understanding according to its main mission as the desimination of rahmatan lil alamin tenet and world peace spirit. ${ }^{17}$

49, No. 2 Desember 2015, pp. 298-314; Nuruddin, “Basis Nilai-nilai Perdamaian Sebuah Antitesis Radikalisme Agama di Kalangan Mahasiswa", HARMONI: Journal of Multicultural \& Multireligious, Vol. 12, No. 3, September-Desember 2013, pp. 68-69; Muhammad Harfin Zuhdi, "Fundamentalisme dan Upaya Deradikalisasi Pemahaman AlQur'an dan Hadis", RELIGIA: Jurnal Studi Agama-agama, Vol. 15 No. 1, April 2012, pp. 81-102; Syamsul Arifin \& Hasnan Bachtiar, "Deradikalisasi Ideologi Gerakan Islam Transnasional Radikal”, HARMONI: Jurnal Multikultural 
Based on the definition and its scope, deradicalization is expected not only as the government duty but also those who are in the state, civil, and business society. Basically, all religion teach love and respect. Their message is to live in peace with all God's creatures. There is no religion that encourages the people to act radically, anarchically and spread terror. This is the challenge in this global era. It is also the duty for the whole elements of the society, especially religion leaders, intellectuals, academicians and politicians to recognize the religious moral values. It will bring the harmonic life of plural society. The anarchy, radical, and destructive acts conducted by the radical community are absolutely diametrically contradicts the religious principles.

Therefore, the psychological implication of religion radicalism and the other violence will make the religions, especially Islam, are reduced as terrifying shadow and lose their humanity aspects. The beauty of religion will be faded and turn into rage and its inspiration turns to arrogance. The plurality that is developed upon emotional intelligence and argumentative thought turn to destructive power in form of bombing, massacre, and death. This will not give awareness impact and transformation of Islam noble moral value.

\section{Conclusion}

The religion radicalism emergence is caused by a wide range of complicated factors. One of them is the understanding aspect of the religion fundamental tenet which is literal-scriptural, rigid, and tends to self-truth claiming. This main character is related to their understanding and interpretation of jihad doctrine, that is rigid and literal. The violence ideology namely Jihad is frequently used as legitimization to do violent acts using distorted interpretation. The religion interpretation monopoly leads to a destructive implication in the social life.

\& Multireligius, Vol 12 No 3, September-Desember 2013, pp. 19-36; Ahmad Darmadji, "Pondok Pesantren dan Deradikalisasi Islam di Indonesia”, Jurnal Millah, Vol. XI,
Radicalism ideology is often employed to legitimate the violence conducted by certain people through the distorted interpretation of jihad. This monopoly brings the destructive implication to the society so it seems that this interpretation is the main focus in religious life. In fact, the religion's holy mission is different from what is expressed by the radicalists who lean on jihad interpretation. Thus, the deradicalization of religion understanding must be implemented.

\section{References}

Abaza, Mona. "The Discourse on Islamic Fundamentalism in the Middle East and Southeast Asia: A Critical Perspective". Sojourn Vol. 6, 1991, pp. 203-239;

Ahady, Anwar-ul-Haq. "The Decline of Islamic Fundamentalism". Journal of Asia and African Studies, Vol. XXVII, No. 3-4, 1992;

Ahyar, Muzayyin. "Membaca Gerakan Islam Radikal dan Deradikalisasi Gerakan Islam". Walisongo, Vol. 23, No. 1, Mei 2015, pp. 126;

Anwar, M. Syafi'i. "Dekonstruksi Fatalisme Keagamaan". Jawa Post, 26 September 2009;

Arifin, Syamsul \& Hasnan Bachtiar. "Deradikalisasi Ideologi Gerakan Islam Transnasional Radikal". HARMONI: Jurnal Multikultural \& Multireligius, Vol. 12 No. 3, SeptemberDesember 2013, pp. 19-36;

Arifin, Syamsul. "Membendung Arus Radikalisasi di Indonesia". ISLAMICA: Jurnal Studi Keislaman, Vol. 8, No. 2, Maret 2014, p. 392420;

Asrori, Ahmad. "Radikalisme di Indonesia: Antara Historisitas dan Antropisitas". Kalam: Jurnal Studi Agama dan Pemikiran Islam, Vol. 9 No. 2, Desember 2015, pp. 253-268;

Azra, Azumardi. "Radikalisme Islam Indonesia". Tempo, 15 Desember 2002;

"Fenomena Fundamentalisme dalam Islam”. Ulumul Qur'an, Vol. IV No. 3, 1993;

Bakri, Syamsul. "Islam dan Wacana Radikaisme Agama Kontemporer". Jurnal DINIKA, Vol. 3 No. 1, Januari 2004; 
Banawiratma, J.B. 1993. Bersama Saudara-Saudari Beriman Lain: Perspektif Gereja Katolik, in Dialog: Kritik dan Identitas Agama. Yogyakarta: Dian Interfidei;

Biyanto. "Fundamentalisme dan Ideologi Islam Modern". PARAMEDIA, Vol. 7 No. 2, April 2006;

BM, St. Aisyah. "Konflik Sosial dalam Hubungan Antar Umat Beragama". Jurnal Dakwah Tabligh, Vol. 15, No. 2, Desember 2014, pp. 189-208;

Bruinessen, Martin van. "Genealogies of Islamic Radicalism in post-Suharto Indonesia", South East Asia Research, Vol. 10 No. 2, 2002, pp. 131-134;

Darmadji, Ahmad. "Pondok Pesantren dan Deradikalisasi Islam di Indonesia". Jurnal Millah, Vol. XI, No. 1, Agustus 2011,

Davis, Michael. "Laskar Jihak and the Political Position of Conservative Islam in Indonesia". Contemporary Southeast Asia, Vol. 24, 2002;

Departemen Pendidikan dan Kebudayaan. 1995. Kamus Besar Bahasa Indonesia. Jakarta: Balai Pustaka;

Dimyati, Khudzaifah.; Muhammad Busjro Mugoddas dan Kelik Wardiono, "Radikalisme dan Peradilan: Pola-pola Intervensi Kekuasaan dalam Kasus Komando Jihad di Indonesia". Jurnal Dinamika Hukum, Vol. 13 No. 3, September 2013, pp. 379-391;

Echols, John M., dan Hassan Shadily. 1995. Kamus Inggris Indonesia (Jakarta: Gramedia;

Effendi, Bahtiar dan Hendro Prasetyo (ed). 1998. Radikalisme Agama. Jakarta: PPIM-IAIN;

Esak, Farid. "Global Insecurities vs Perlawanan Global". Tradem, Fourth Edition, Januay 2003-March 2003, pp 42-43;

Faizin, Khoirul. "Fundamentalisme dan Gerakan Radikal Islam Kontemporer di Indonesia". Edu-Islamica, Vol. 5 No. 2, September 2013, pp. 344-367;

Fanani, Ahmad Fuad. "Radikalisme dan Pembiaran”. Kompas, 30 April 2011;

Fuad, Ahmad Nur. "Interrelasi Fundamentalisme dan Orientasi Ideologi Gerakan Islam Kontemporer". ISLAMICA, Vol. 2 No. 1, September 2007, pp. 16-26;

Hegghammer, Thomas. "Global Jihadism after the Iraq War". Middle East Journal, Vol. 60, No. 1, 2006; pp. 11-32;
Hilmy, Masdar. "Genealogi dan Pengaruh Ideologi Jihadisme Negara Islam Iraq dan Suriah (NIIS) d Indonesia". Teosofi: Jurnal Tasawuf dan Pemikiran Islam, Vol. 4 No. 2, Desember 2014, pp. 404-428;

"Radikalisme Agama dan Politik Demokrasi di Indonesia Pasca-Orde Baru". MIQOT, Vol. XXXIX, No. 2, Juli-Desember 2015, 407-425;

"Radikalisme, Demokrasi dan Pancasila". Kompas, 12 September 2014; p. 7

. "The Politics of Retaliation: The Backlish of Radical Islamist against Deradicalization Project in Indonesia". Al-Ja-mi'ah, Vol. 51, No. 1, 2013/2014, pp 129-158;

Huda, Sokhi. "Terorisme Kontemporer Dunia Islam". Teosofi: Jurnal Tasawuf dan Pemikiran Islam, Vol. 4 No. 2, Desember 2014, pp. 429-450;

Juergensmayer, Mark. 2001. Terror in the Mind of God: The Global Rise of Religious Violence (California: University of California Press;

Kasdi, Abdurrahman. "Fundamentalisme Islam Timur Tengah: Akar Teologi, Kritik Wacana dan Politisasi Agama". Tashwirul Afkar, $13^{\text {th }}$ Edition, 2002;

Khamdan, Muh. 2015. Bina Damai Terorisme Kudus: Parist;

Kolig, Erich. "Radical Islam, Islamic Fervor and Political Sentiments in Central Java, Indonesia". European Journal of East Asian Studies, No. 4 Vol. 1, 2005; pp. 55-86

Kosim, Mohammad. "Pesantren dan Wacana Radikalisme". Jurnal Karsa, Vol. IX, No. 1, April 2006;

Lajnah Pentashihan Mushaf al-Qur'an Kementerian Agama, 2014, Tafsir al-Qur"an Tematik Jilid I, Jakarta: Kamil Pustaka, p. 97.

Lutz, James M. dan Brenda J. Luts. 2004. Global Terrorism. London: Routledge;

Machasin. "Fundamentalisme dan Terorisme", dalam A. Maftuh Abegebriel, et.al. 2003. Negara Tuhan: The Thematic Encyclopedia. Yogyakarta: Pustaka Pelajar;

Mubarak, M. Zaki. "Dari NII ke ISIS: Transformasi Ideologi dan Gerakan dalam Islam Radikal di Indonesia Kontemporer". Episteme, Vol 10 No. 1, Juni 2015, pp. 77-98;

Mulkhan, Abdul Munir. "Transformasi Doktrin untuk Keunggulan Hidup". Jawa Pos, 1 Oktober 2009; 
Mustofa, Imam. "Terorisme: Antara Aksi dan Reaksi (Gerakan Islam Radikal sebagai Respon terhadap Imperialisme Modern)". RELIGIA: Jurnal Studi Agama-agama, Vol. 15 No. 1, April 2012, pp. 65-87;

Nesira, Hani. "Who Leads Global Jihad, al-Qaeda or ISIS?". al-Arabiya Institute for Studies, 19 Juni 2014, www.alarabiya.net, akses 5 Desember 2017;

Nuruddin. "Basis Nilai-nilai Perdamaian Sebuah Antitesis Radikalisme Agama di Kalangan Mahasiswa". HARMONI: Journal of Multicultural \& Multireligious, Vol. 12, No. 3, September-Desember 2013, pp. 68-69

Ratnasari, Dwi. "Fundamentalisme Islam". Komunika: Jurnal Dakwah dan Komunikasi, Vol. 4 No. 1, Januari-Juni 2010, pp. 40-57;

Ro'uf, Abdul Mukti. "Mengurai Radikalisme Agama di Indonesia Pasca Orde Baru". Ulumuna: Jurnal Studi Keislaman, Vol. XI, No. 1, Juni 2007, pp. 157-176

Rokhmad, Abu. "Pandangan Kiai tentang Deradikalisasi Paham Islam Radikal di Kota Semarang". Jurnal "Analisa", Vol. 21 No. 01 Juni 2014, pp. 27-37;

Rokhmad, Abu. "Radikalisme Islam dan Upaya Deradikalisasi Paham Radikal". Walisongo, Vol. 20 No 1, Mei 2012, pp. 79-114;

Saifuddin. "Radikalisme di Kalangan Mahasiswa, Sebuah Metamorfosa Baru". Islamic Study Journal Analysis, Vol. XI No. 1, June 2011, pp. 28-29

Sephard, William E. "Islam and Ideology: Toward a Typhology". International Journal of Middle East Studies, Vol. 19, 1987, pp 305307;

Shari'ati, Ali. 1993. Ideologi Kaum Intelektual: Suatu Wawasan Islam, (edited by Syafiq Basri dan Haidar Bagir). Bandung: Mizan;

Shepard, William E. "Fundamentalism Christian and Islamic". Religion, Vol. 17, No. 1 1987, pp. 355-378;

Shepard, William E. "What is Islamic Fundamentalism?". Studies in Religion, Vol. 18, No. 1, 1988, pp. 5-25;

Sholehuddin, Moh. "Ideologi Religio-Politik Gerakan Salafi Laskar Jihad Indonesia". Jurnal Review Politik, Vol. 03, No. 1, Juni 2013, pp. 47-68;

Tahir, Masnun. "Wacana Fikih Kebangsaan dalam Penanggulangan dan Pencegahan Radikalisme di Lingkungan Kampus di NTB".
Asy'Syir'ah: Jurnal Ilmu Syari'ah dan Hukum, Vol. 49, No. 2 Desember 2015, pp. 298-314

Tibbi, Bassam. "Kaum Fundamentalis Jadikan Islam sebagai Ideologi Politik". Tashwirul Afkar, $13^{\text {th }}$ Edition, 2002;

Turmudzi, Endang dan Riza Sihbudi (eds). 2005. Islam dan Radikalisme di Indonesia. Jakarta: LIPI Press;

Zuhdi, Muhammad Harfin. "Fundamentalisme dan Upaya Deradikalisasi Pemahaman AlQur'an dan Hadis". RELIGIA: Jurnal Studi Agama-agama, Vol. 15 No. 1, April 2012, pp. 81-102. 